\title{
Fantasy Pitching
}

Robert Faffal, Searat Ali ${ }^{\mathrm{b}}$, Muhammad Atif ${ }^{\mathrm{b}}$, Matt Brenner ${ }^{\mathrm{a}}$, Hasibul Chowdhury ${ }^{\mathrm{a}}$, Leelyn Crudas ${ }^{\mathrm{a}}$, Alison Joubet ${ }^{\mathrm{a}}$, Ihtisham Malik $^{\mathrm{a}}$, Lin Mi ${ }^{\mathrm{a} ;}$; Vinu Nagar ${ }^{\mathrm{c}}$, Tim Pullen ${ }^{\mathrm{a}}$, Manuel Siegrist ${ }^{\mathrm{d}}$, Steve Smythe ${ }^{\mathrm{a}}$, Jeff Stephenson ${ }^{\mathrm{d}}$, Beile Zhang ${ }^{\mathrm{a}}$ and Kun Zhang ${ }^{\mathrm{a}}$

\author{
${ }^{a}$ University of Queensland, Australia \\ ${ }^{\mathrm{b}}$ Griffith University, Australia \\ ${ }^{c}$ Swinburne University, Australia \\ ${ }^{\mathrm{d}}$ Bond University, Australia
}

\begin{abstract}
This paper outlines a fantasy research pitch exercise conducted in a $\mathrm{PhD}$ course at the University of Queensland. Using Faff's $(2015,2017)$ pitching research template, students attending the course were asked to engage in a group exercise to pitch a "fantasy" research topic. While the final exercise was completed in a 90-minute timeframe ( 60 minutes of brainstorming, followed by 30 minutes of reporting back to the full group), the cohort had already been exposed to $5 \mathrm{x} 90$ minute sessions of related material over the weekend $\mathrm{PhD}$ module. Three groups of five were formed and they pitched three "fun" (or nonsense) topics: (a) Teenage Mutant Ninja Turtles: Impact on Society; (b) Wipe-a-Baby; (c) Quality of Dairy Products: The Happiness of the Cow Does Matter.
\end{abstract}

Keywords: Pitching Research; Fantasy Pitching; PhD Student Exercise; Research Group-work Exercise

JEL codes: G00; M00; B40; A20; B00; C00; D00; E00; F00; H00; I00; J00; L00; Q00; R00; Z00

${ }^{1}$ Corresponding author: UQ Business School, The University of Queensland, Queensland 4072 Australia, Telephone: (61) 73346 8055, E-mail address: r.faff@business.uq.edu.au 


\section{Introduction}

Faff's $(2015,2017)$ pitching research concept provides a simple 2-page template tool. ${ }^{\text {iii }}$ The aim is to present a tool SO THAT a novice researcher can confidently and succinctly convey all the essential elements of a new research proposal to an academic expert. iii The pitching tool is both methodical and succinct in its design. The current paper provides a brief narrative describing a pitch exercise conducted in a $\mathrm{PhD}$ course at the University of Queensland, using Faff's $(2015,2017)$ pitching research template. Specifically, students attending the course were asked to engage in a group exercise to pitch a "fantasy" research topic. Before moving on to describe the "fantasy pitching" exercise, some further background to the pitching research concept is worthwhile. Most notably, this background will cover related papers: Faff (2016a, 2016b); Faff et al. (2017) and Faff et al. (2016). ${ }^{\text {iv }}$

Faff (2016a) reviews experiences and draws insights from a series of workshops, pitch days, competitions and other events based on the "pitching research" template tool. With, in excess of 80 , unique events primarily conducted throughout the calendar year 2015, this intense program of activity culminated in the Final of a "pitching" competition at the University of Queensland sponsored by the UQ Association of Postgraduate Students (UQAPS) on $4^{\text {th }}$ November, 2015. The UQAPS 2015 event captured the full spectrum of academic discipline areas: from mechanical engineering to ... tourism to ... virology and more. ${ }^{\mathrm{v}}$ Faff (2016c) and Faff et al. (2017) provide companion pieces that, among other things, capture key themes from the second edition of the UQuAPS competition held in November 2016.

Faff (2016b) takes a "learning" perspective, setting the scene for the current pedagogic focused paper. Specifically, Faff (2016b) maps versions of Faff's (2015, 2017) pitching research template designed for student tasks/assessment into the research skill development (RSD) framework of Willison and O'Regan (2007). Moreover, using the 7-level RSD7 version, Faff (2016b) explains how meaningfully layered pitching tasks can be designed to give a wide range of students an appropriately calibrated research challenge. At one end of the spectrum, a "Level 1" "prescribed research" task (i.e. lowest degree of difficulty in the RSD7 framework) would be a "partial" pitch based on reverse-engineering a designated short and simple research article that has been authored by a third party. At the other end of the spectrum, a "Level 7" "enlarging research" challenge (i.e. highest degree of 
difficulty in the RSD7 framework) would be involve a full pitch of a brand new idea, with choice on each and every dimension totally in the hands of the pitcher (student/researcher) about their own research plan(s) (e.g. a plan for one essay in their $\mathrm{PhD}$ thesis).

Faff et al. (2016) extend the pedagogic angle on pitching a step further. That paper provides a narrative focused on the experiences of a visiting undergraduate exchange student from China to the University of Queensland, Jie Teng. Jie had approached the first author inquiring about opportunities for research projects. Recognizing that the student had only limited exposure to research and an unknown appreciation of what it entails, the mentor devised a program of incremental "discovery" and learning, based on Faff's (2015, 2016) "pitching research" template tool. Under close guidance, Jie was asked to choose a recent academic paper of interest to him and then to reverse engineer a "pitch" for that chosen paper. The pitching process was completed, in 10 small stages, over a period of about 5 weeks. Faff et al (2016) provides a narrative of this research journey aimed at helping other research mentors facing similar situations.

Launching off the above-mentioned "learning" focused papers, namely, Faff (2016b) and Faff et al. (2016), the current paper takes this pedagogic theme even further in terms of the fantasy pitching exercise, for groups of $\mathrm{PhD}$ students. The remainder of the current paper is organised as follows. Section 2 provides a brief background to the exercise which confronted the $\mathrm{PhD}$ students. Section 3 describes the initial fantasy pitch presented by the course leader as an illustrative example of what each group were asked to do. Section 4 describes each of the group created fantasy pitches. Section 5 concludes.

\section{Background to the Fantasy Pitching Group Exercise in the AFDEN PhD Course "Process of Research in Business"}

The contextual setting of the current paper is the AFDEN PhD course: "The Research Process in Business". vi This particular course is partitioned into three weekend modules: (1) "challenges and strategies for starting research"; (2) "challenges and strategies for progressing research"; and (3) "challenges and strategies for finishing research and "beyond"'. On the weekend of 5-6 March, 2016, fifteen $\mathrm{PhD} / \mathrm{PhD}$-track students attended Module \#1 of this course. On the first day we looked at how to generate research ideas and strategies for igniting research creativity. In the morning on day \#2 of Module \#1, was a 90-minute talk on "pitching research" of Faff $(2015,2017)$. The 
talk was broken up as: a general discussion of the underlying philosophy of the pitching tool, then a hypothetical pitch of the pitching tool itself and finishing with a fantasy pitch - "Mickey Mouse and Climate Change". The main benefit of the fantasy example is that it works for a diverse audience as was the case in the course (a mix of Tourism, Strategy, Finance, Management and Marketing students). Also, the fantasy setting allows a more relaxed and "fun" perspective, opening up a greater chance for seeing the full value of the tool.

While the fantasy pitch exercise itself was completed in a 90-minute timeframe (60 minutes of brainstorming, followed by 30 minutes of reporting back to the full group), as described above, the cohort had already been exposed to $5 \times 90$ minute sessions of related material over the weekend module. Three groups of five students were formed and they pitched three "fun" (intentionally nonsense) topics: (a) Teenage Mutant Ninja Turtles: Impact on Society; (b) Wipe-a-Baby; (c) Quality of Dairy Products: The Happiness of the Cow Does Matter. Such fantasy applications of the "pitching" approach, provide a low stress setting for appreciating and exploring the underlying philosophy of the tool. However, given the severe time constraints for the exercise, readers are cautioned not to be overly judgmental about the specifics contained in each pitch.

\section{Mickey Mouse and Climate Change}

Table 1 presents a completed fantasy pitch about "Mickey Mouse and Climate Change". This is a nonsense example that the lead author has used on many occasions in various pitch talks he has given around the world. ${ }^{\text {vii }}$ It is a worked "fantasy" pitch example that has the great advantage of being easily understood by students in any discipline area - thus allowing an uncomplicated appreciation of the underlying components of the template and their role.

One "trick" that individuals can do in the context of this fantasy pitch example, is to substitute out for the key terms "Mickey Mouse" and "climate change", with terms relevant and meaningful in one's own discipline area. For example, a researcher primarily interested in corporate governance research could: (a) replace "Mickey Mouse" with "weak corporate governance" and (b) replace "Climate Change" with "financial crises". In this way the working title becomes: "Weak corporate governance and financial crises". Further, in Table 1 the research question is stated as: "Whether and 
to what extent Mickey Mouse is responsible for climate change?", which in the current example would convert into: "Whether and to what extent weak corporate governance is responsible for financial crises?"

Of course, such a translation of the nonsense "Mickey Mouse" pitch will only work up to a point. For example, moving down to Item E, "Idea", the template begins: "The basic idea is to take a direct approach: to see if the sinister side of Mickey Mouse can be discovered by interviewing his friends...". Translating this, would give us: "The basic idea is to take a direct approach: to see if the sinister side of weak corporate governance can be discovered by interviewing his friends..." Without meaningful adaptation, this clearly doesn't make sense. Nevertheless, despite this limitation, as a "pedagogic" devise, the Mickey Mouse example works just fine. Figure 1, illustrates the graphical approach to showing the novelty of the fantasy pitch - here "Mickey Mouse of Mickey Mouse". The Venn diagram shows the intersection of three salient features: (a) Mickey Mouse (or e.g. weak corporate governance); (b) climate change (or e.g. financial crises); and (c) interviews.

\section{Three Fantasy Pitch Examples from Student Groups}

\subsection{Teenage Mutant Ninja Turtles Fantasy Pitch}

Figure 2 shows the actual handwritten Fantasy Pitch Template for teenage mutant ninja turtles ("TMNT"), as produced by Group \#1 of AFDEN PhD students. Table 2 presents the counterpart word-processed fantasy pitch. As indicated in the table, the proposed study aims to analyse the impacts of TMNT, going beyond the popular belief about the likely negative impacts of TMNTs, to consider whether they have any positive impacts on society. The chosen setting is the Brisbane city area. As indicated in Item E (Idea), an interpretive inquiry is planned in which various actors will be interviewed and surveyed (Item F). In terms of Item G, Tools, Qualtrics, SPSS and NVivo are the key aspects.

\subsection{Wipe-a-Baby Fantasy Pitch}

Figure 3 shows the presentation slides for the Fantasy Pitch Template for "wipe-a-baby", as produced by Group \#2 of AFDEN PhD students. Table 3 presents the counterpart word-processed fantasy pitch. Group \#2 pose the question - is the baby mop a feasible innovation? While not so clear in the materials here, in the class oral presentation it was made clear that the basic 
idea is to attach a light-weight mop to the underside of a crawling baby - as the (pre-walking) baby crawls around on the floor, the mop will have a natural cleaning effect. Hence the name, "wipe" "a" "baby". As indicated by the two key questions: $(\mathrm{H})$ what's new?: the novelty is using babies as mops; (I) So what?: considerable time and cost savings for the stay at home parent. Also of note in this pitch, is shown in the final item of Table 3, other considerations. Specifically, Group \#2 recognise that security and ethics are important to highlight in this fantasy pitch - noting that the mop is soft and safe, taking advantage of "natural" baby movements. Finally, the second-last slide in Figure 3 shows the Mickey Mouse diagram - here the triple intersection novelty involves: (a) baby; (b) economic potential; and (c) field experiments.

\subsection{Quality Dairy Products Fantasy Pitch}

Table 4 shows the word-processed Fantasy Pitch Template for "quality dairy products", as produced by Group \#3 of AFDEN PhD students. This pitch makes the case for linking the emotions of the cow and the consumer and particularly that the happiness of the cow does matter. The third aspect of the basic research question (Item B) is the essence of the pitch and is inherently appealing (despite its clear nonsensical nature): how (well) does a dairy product made from a happy animal influence the happiness of consumers? This is reinforced in Item E, Idea, with the suggestion that the moods of the cow and people a linked.

\section{Conclusion}

This paper provides a narrative record of a pedagogic experiment involving a fantasy research pitch exercise conducted in a PhD course at the University of Queensland. Specifically, using Faff's (2015, 2017) pitching research template, students attending the course were asked to create a "fantasy" research pitch. Three groups of five students were formed and they pitched three fantasy topics: (a) Teenage Mutant Ninja Turtles: Impact on Society; (b) Wipe-a-Baby; (c) Quality of Dairy Products: The Happiness of the Cow Does Matter. Given the time constraints for the exercise, such a fantasy application of the "pitching' approach, provides a low stress setting for appreciating and exploring the underlying philosophy of the tool. 


\section{References}

Ali, S. (2016) "Corporate governance and stock liquidity in Australia: A pitch", Accounting and Management Information Systems, vol. 15, no. 3: 624-631

Atif, M. (2016) “CEO compensation and firm's cash holding: A pitch", Accounting and Management Information Systems, vol. 15, no. 3: 605-611

Beaumont, S. (2015) "An Investigation of the Short and Long Run Relations between Executive Cash Bonus Payments and Firm Financial Performance: A Pitch", Accounting \& Finance, vol. 55: 337-343

Brenner, M. (2016) "Investigating chef-leader behaviour impacts on subordinate work team identification: A pitch", Accounting and Management Information Systems, vol. 15, no. 4: 826-834

Chang, M. \& Wee, M. (2016) "The effect of voluntary versus mandatory adoption of trading policies on the returns to insider trades", Pacific-Basin Finance Journal, vol. 38: 76-87

Dang, M. \& Henry, D. (2016) "Partial-control versus Full-control acquisitions: Does target corporate governance matter? Evidence from eight East and Southeast Asian nations", Pacific-Basin Finance Journal, vol. 40: 251-265

Ellis, P. (2016) "To find a standard format that measures the activities of a Micro, Small or Medium Business Entity. A Pitch", Accounting and Management Information Systems, vol. 15, no. 2: 420-427

Faff, R.W. (2015) “A Simple Template for Pitching Research”, Accounting \& Finance, vol. 55: 311-336

Faff, R.W. (2016a) "The "Pitching Research" Concept: 2015, a Year in Review", Available at SSRN: http://ssrn.com/abstract=2721528 or http://dx.doi.org/10.2139/ssrn.2721528

Faff, R. (2016b) "Mapping "Pitching Research" Tasks into the RSD7 Framework: A Pedagogic Perspective". Available at SSRN: http://ssrn.com/abstract=2724451

Faff, R.W. (2016c) 'Learning from 'Pitching Research' Competition Winners: Insights and Reflections" (December 30, 2016). Available at SSRN: https://ssrn.com/abstract=2891650

Faff, R.W. (2017) "Pitching Research", Version 13 (or beyond) Available at SSRN: http://ssrn.com/abstract=2462059 or http://dx.doi.org/10.2139/ssrn.2462059

Faff, R., Godfrey, K. \& Teng, J. (2016) "Pitching Research Evolution: An Illustrative Example on the Topic of 'Innovation and Financial Dependence"" (May 7, 2016). Available at SSRN: http://ssrn.com/abstract=2776959 or http://dx.doi.org/10.2139/ssrn.2776959

Faff, R.W., Lay, J. \& Smith, M, (2017) "PoW! Using Social Media to Leverage Research Visibility - "Pitch of the Week" Posts in LinkedIn" (January 4, 2017). Available at SSRN: https://ssrn.com/abstract $=2894069$

Faff, R., Ali, S., Atif, M., Brenner, M., Chowdhury, H., Crudas, L., Joubet, A., Malik, I., Nagar, V., Mi, L., Pullen, T., Siegrist, M., Smythe, S., Stephenson, 
J., Zhang, B., and Zhang, K. (2016) "Fantasy Pitching", Available at SSRN: http://ssrn.com/abstract=2782778 or http://dx.doi.org/10.2139/ssrn. 2782778

Faff, R.W. \& Kastelle, T. (2016) "Pitching Research for Engagement and Impact" (July 22, 2016). Available at SSRN: http://ssrn.com/abstract=2813096 or http://dx.doi.org/10.2139/ssrn.2813096

Faff, R.W., Li, Y., Nguyen, B.H. \& Ye, Q. (2016) "Pitching Research: A Pilot Experiment with UQ Winter Scholars" (July 30, 2016). Available at SSRN: http://ssrn.com/abstract=2816233

Faff, R.W., Wallin, A., Brosnan, M., Carrillo, N., Darmawan, D., Dorris, A., Groen, M., Listiani, N., Maxwell, V., Orole, F., Pham, A., Salehudin, I., Simons, M., To, D., Tsoi, J., Wong, C., Woods, K., Yossa, N., Zhaunerchyk, K. (2016) "Fantasy Pitching II: Star Wars vs. Pokemon vs. R\&D vs. Uber" (August 22, 2016). Available at SSRN: http://ssrn.com/abstract $=2827425$

Faff, R.W., Carrick, R., Chen, A., Dallest, K., Escobar, M., Foley, G., Gill, C., Khong, B.X.M., Liu, M., McCullough, J., Ndugwa, Z., Nguyen, B.H., O'Brien, S., Orole, F., Qureshi, A., Rad, H., Rekker, S., Shahzad, S.K., Smith, M., Tunny, W. \& Wallin, A (2017) "Motivating Postgrad Research Students to Pitch Their Ideas: What Have We Learned from "Pitching Research" Competitions at UQ?" (January 15, 2017). Available at SSRN: https://ssrn.com/abstract $=2899942$

Faff, R.W., Carrick, R., Chen, A., Escobar, M., Khong, B.X.M., Nguyen, B.H. \& Tunny, W. (2017a) "Pitching Research: A Reverse-Engineer "Sparring" Experiment with UQ Summer Research Scholars" (January 23, 2017). Available at SSRN: https://ssrn.com/abstract=2903811

Faff, R.W., Carrick, R., Chen, A., Escobar, M., Khong, B.X.M., Nguyen, B.H. \& Tunny, W. (2017b) "Fantasy Pitching III: UQ Summer Research Scholars the Role of "Money" in the $21^{\text {st }}$ Century" (January 26, 2017). Available at SSRN: https://ssrn.com/abstract=2906617

Lee, G. \& Turner, M. (2017) "Do Government Administered Financial Rewards Undermine Firms' Internal Whistle-Blowing Systems? A Pitch", Accounting Research Journal, forthcoming

Mathuva, D. (2016) "Drivers of financial and social disclosure by savings and credit cooperatives in Kenya: A managerial perspective", Journal of Co-operative Organization and Management, vol. 4: 85-96

Maxwell, V. (2017) "Developing a Research Agenda through Pitching", unpublished manuscript. Available at: http://bit.ly/2ihJ3lb

McKay, W. \& Haque, T. (2016) "A study of industry cost of equity in Australia using the Fama and French 5 Factor model and the Capital Asset Pricing Model (CAPM): A pitch", Accounting and Management Information Systems, vol. 15, no. 3: 618-623

Menzies, G., Dixon, P. \& Rimmer, M. (2016) "In Praise of (Some) Red Tape: A New Approach to Regulation”, Economic Record, vol. 92: 631-647 
Nguyen, B.H., Faff, R.W. \& Haq, M. (2017) "Pitching Research Lite: A ReverseEngineering Strategy for Finding a New Research Direction" (February 1, 2017). Available at SSRN: https://ssrn.com/abstract=2909549

Qureshi, A. (2016) "Conceptualizing Schwartz values in university preference decisions: A pitch", Accounting and Management Information Systems, vol. 15, no. 3: 612-617

Rad, H. (2016) "Pairs trading and market efficiency using an adaptive market hypothesis framework: A pitch", Accounting and Management Information Systems, vol. 15, no. 1: 178-185

Rahman, D. (2016) "Investor sentiment, Executive compensation, and Investment Some International evidence: A Pitch", Accounting and Management Information Systems, vol. 15, no. 2: 428-433

Ratiu, B. (2016) "A reversed engineered pitch based on Rietveld (2016), "Creating value through the freemium business model: A consumer perspective", Accounting and Management Information Systems, vol. 15, no. 4: 810-818

Ratiu, R.V. (2015) "Financial Reporting of European Banks during the GFC: A Pitch", Accounting \& Finance, vol. 55: 345-352

Rekker, S. (2016) "Converting planetary boundaries into action, a new approach to meeting global greenhouse gas targets: A pitch", Accounting and Management Information Systems, vol. 15, no. 1: 160-167

Salehudin, I. (2017) “"Reverse Engineering” the Pitching Research Template: A Simple Tool to Help Understand the Academic Literature", Accounting and Management Information Systems, vol. 16(1): 203-210

Shahzad, S.K. (2016) "Private firms' adaptation to climate change within the context of developing countries: A pitch", Accounting and Management Information Systems, vol. 15, no. 1: 168-177

Sinnewe, E. (2017) "Is Less More? Does Integrated Reporting Lead to a Desirable Level of Reporting Conciseness?: A Pitch", Accounting Research Journal, forthcoming

Sivathaasan, N. (2016) "Corporate governance and leverage in Australia: A pitch", Accounting and Management Information Systems, vol. 15, no. 4: 819-825

Sivathaasan, N., Ali, S., Liu, B. \& Haung A. (2017) "Stock Liquidity, Corporate Governance and Leverage: New Panel Evidence", Pacific-Basin Finance Journal, forthcoming

Teng, J. and Faff, R.W. (2017) “A "Snowballing” Pedagogic Strategy for Pitching Research: An Illustrative Example in Finance" (January 25, 2017). Available at SSRN: https://ssrn.com/abstract=2906127

Truong, T.P. \& Nguyen, N. (2017) "Regulatory Enforcement, Financial Reporting Quality and Investment Efficiency: A Pitch", Accounting Research Journal, forthcoming

Unda, L. (2015) "Board of Directors Characteristics and Credit Union Financial Performance: A Pitch", Accounting \& Finance, vol. 55: 353-360 
Wallin, A. \& Spry, A. (2016) "The role of corporate versus product brand dominance in brand portfolio overlap: A Pitch", Accounting and Management Information Systems, vol. 15, no. 2: 434-439

Xue, R. (2016) "Study of the contagion mechanism for opening risk of emerging equity markets in BRICS countries: A pitch", Accounting and Management Information Systems, vol. 15, no. 1: 154-159

Zhang, Y. (2017) "Client Importance and Audit Quality, Office Level Evidence from the Banking Industry: A pitch", Accounting Research Journal, forthcoming 
Table 1. Fantasy Pitch \#1 - "Mickey Mouse and Climate Change"

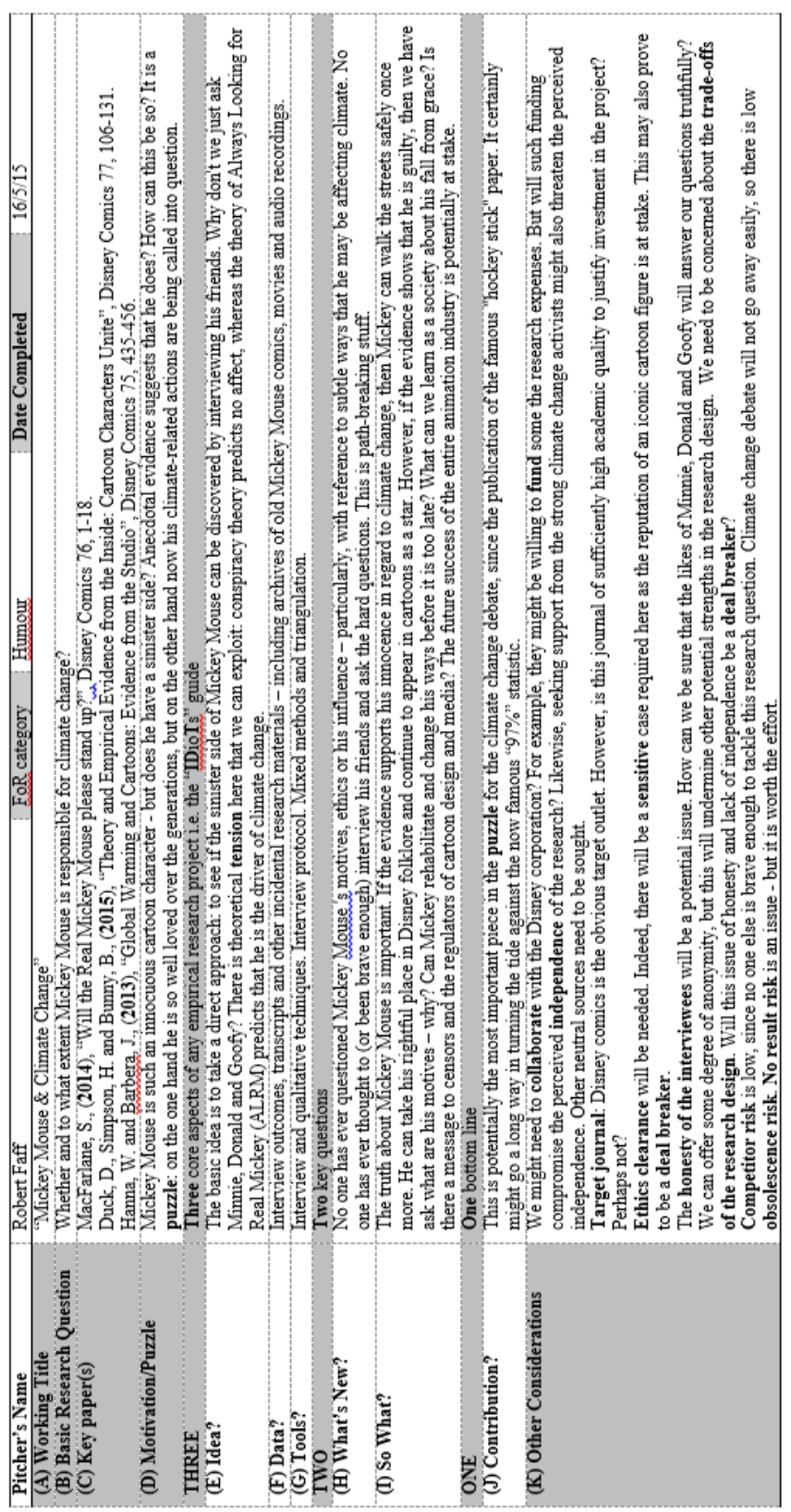

[This pitch is Appendix A35 in the online appendix:

http://www.business.uq.edu.au/sites/default/files/pages/pitchingpaper_internetappendix_a35-humour_16may2015.pdf] 
Table 2. Fantasy Pitch \#2 - "Teenage Mutant Ninja Turtles"

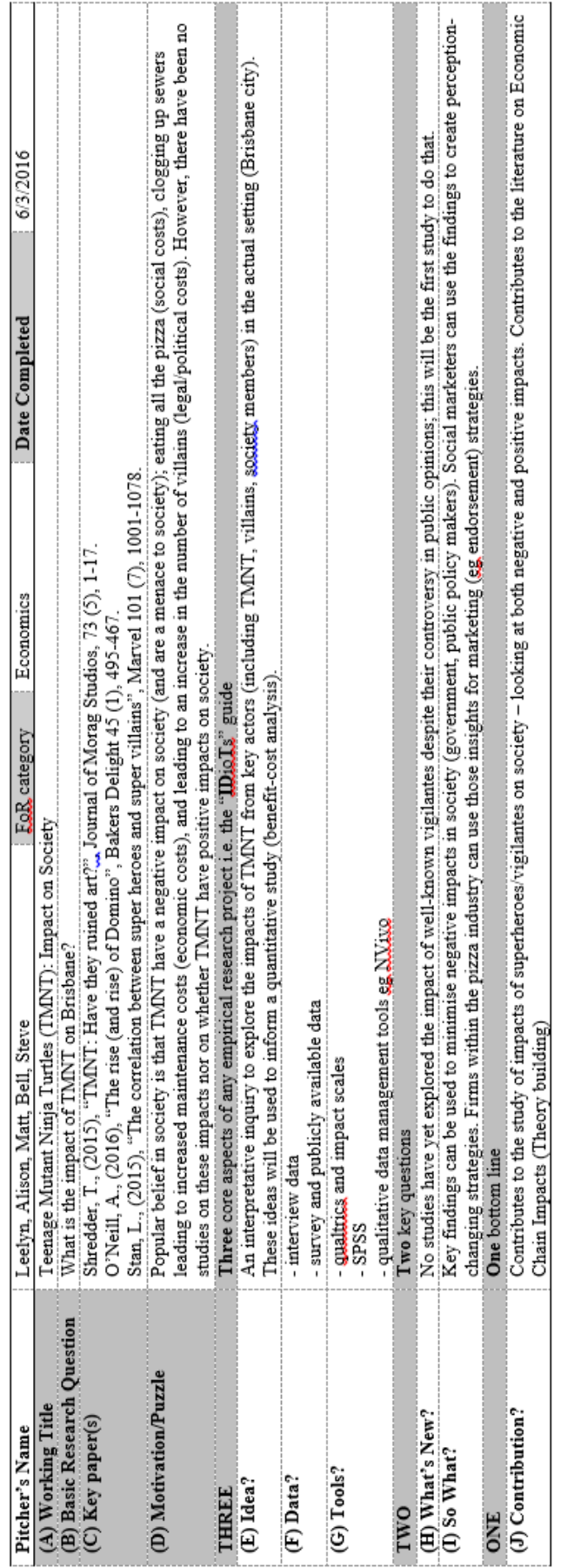

Vol. 16, No. 2 
Table 3. Fantasy Pitch \#3 - "Wipe-a-baby"

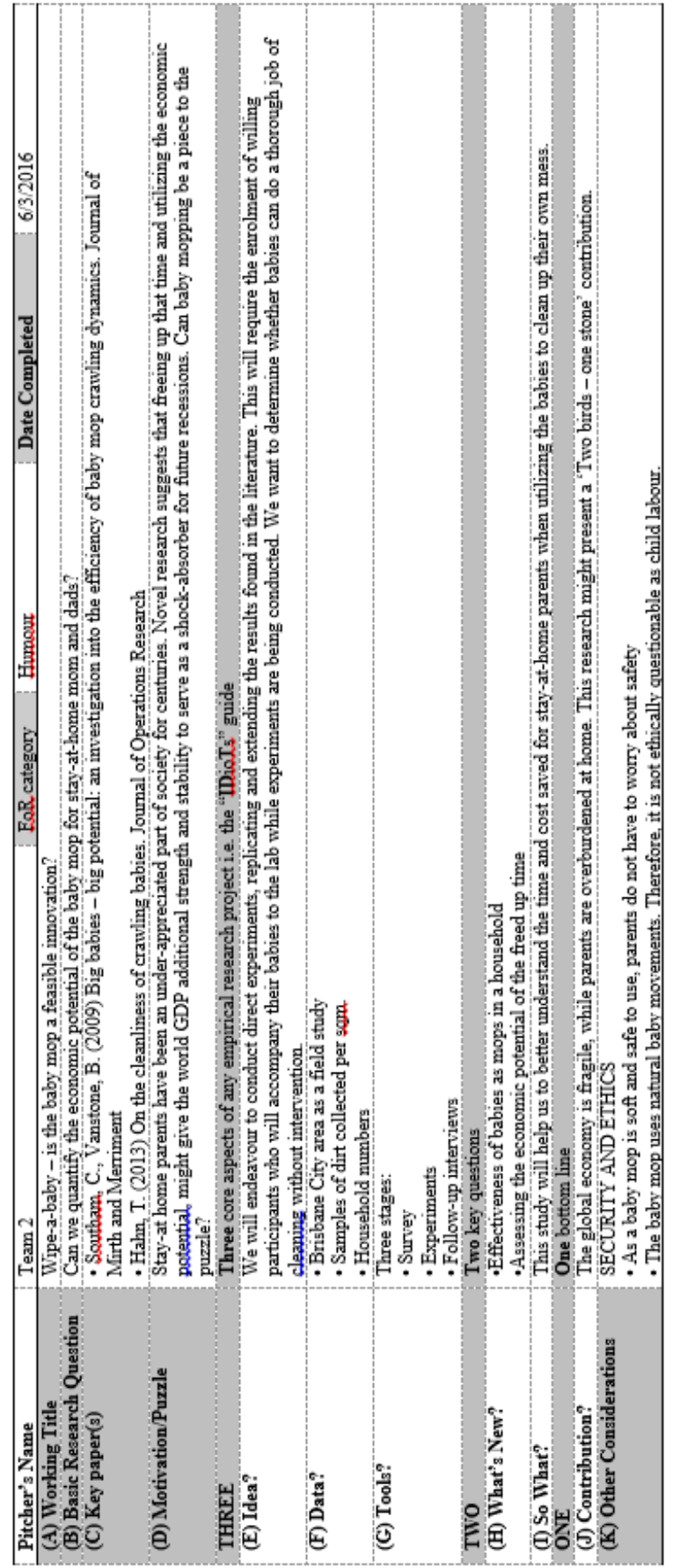


Table 4. Fantasy Pitch \#4 - "Quality Dairy Products"

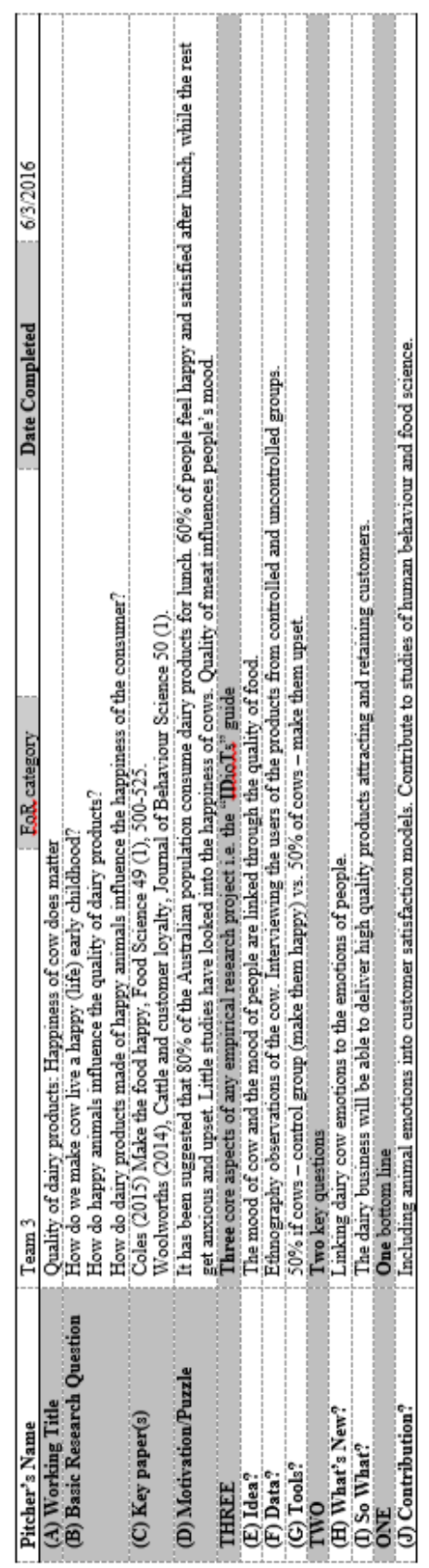

Vol. 16, No. 2 


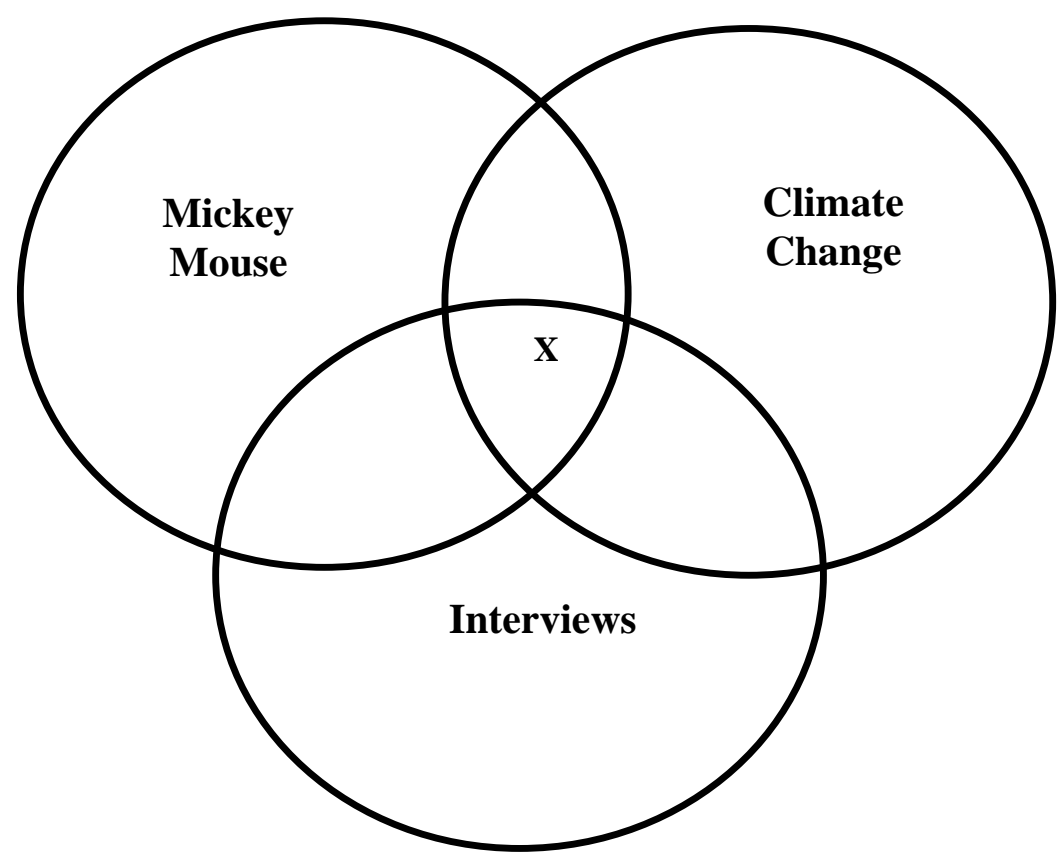

Figure 1. Mickey Mouse of Mickey Mouse 


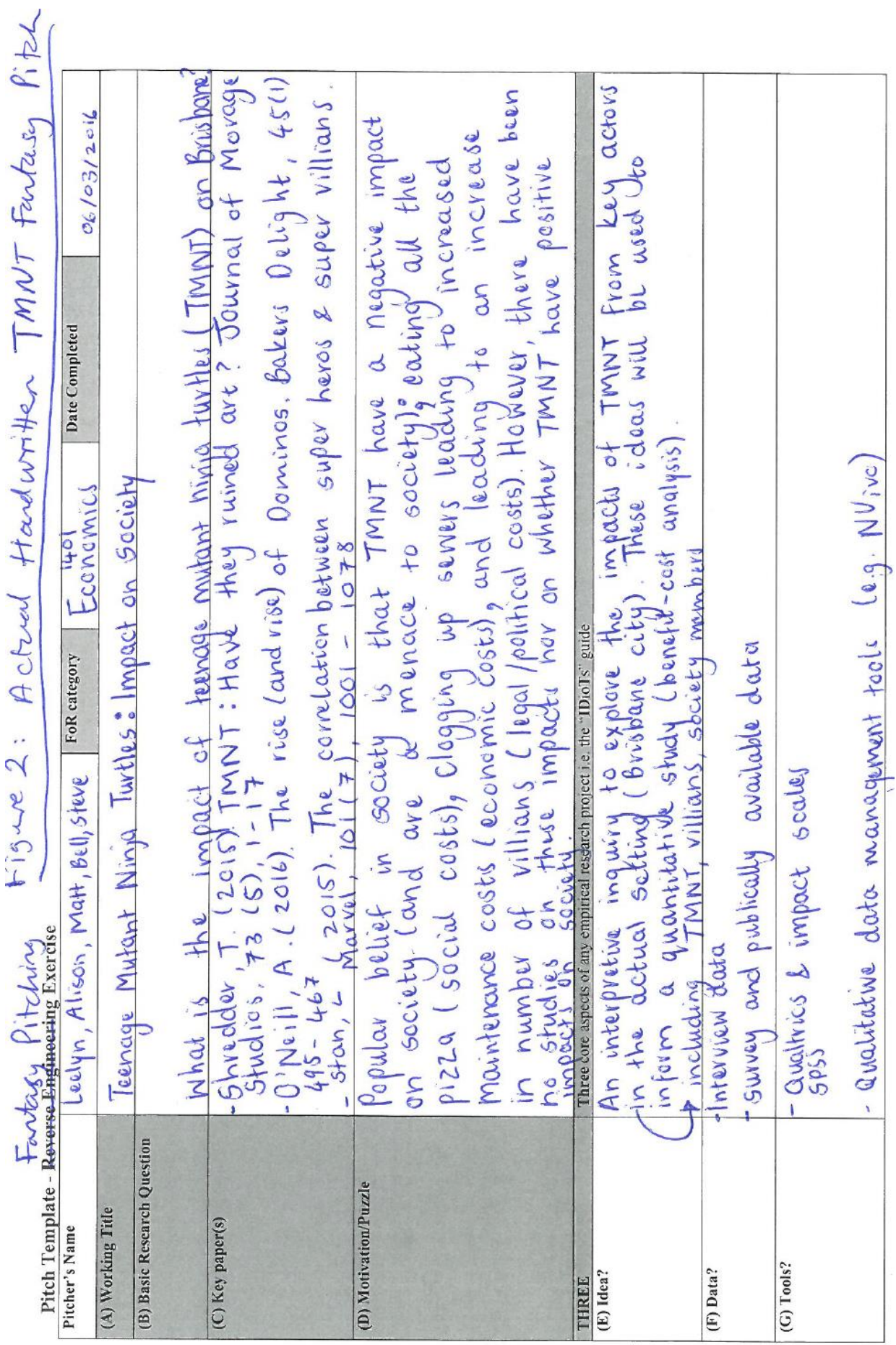

Vol. 16, No. 2 


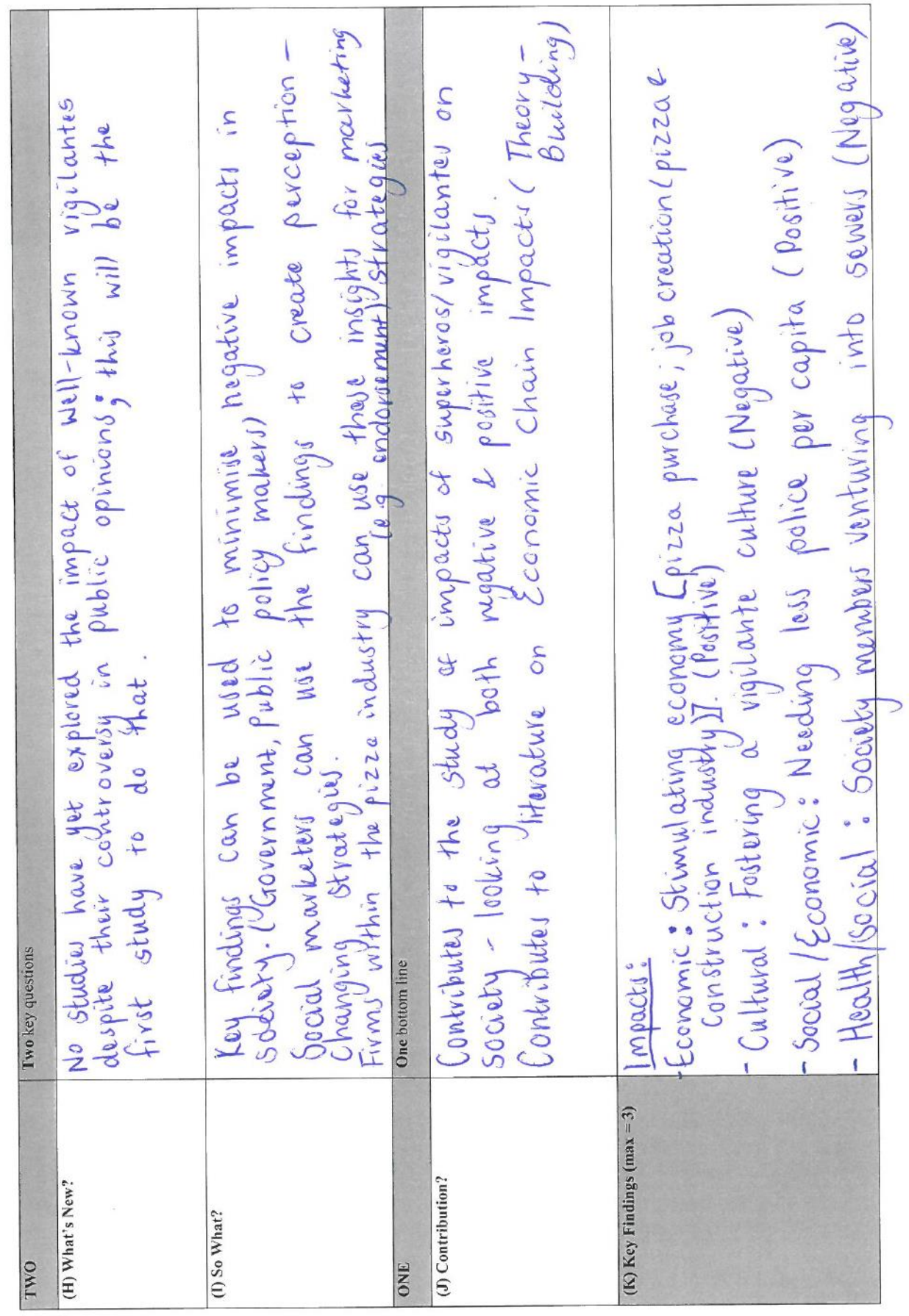



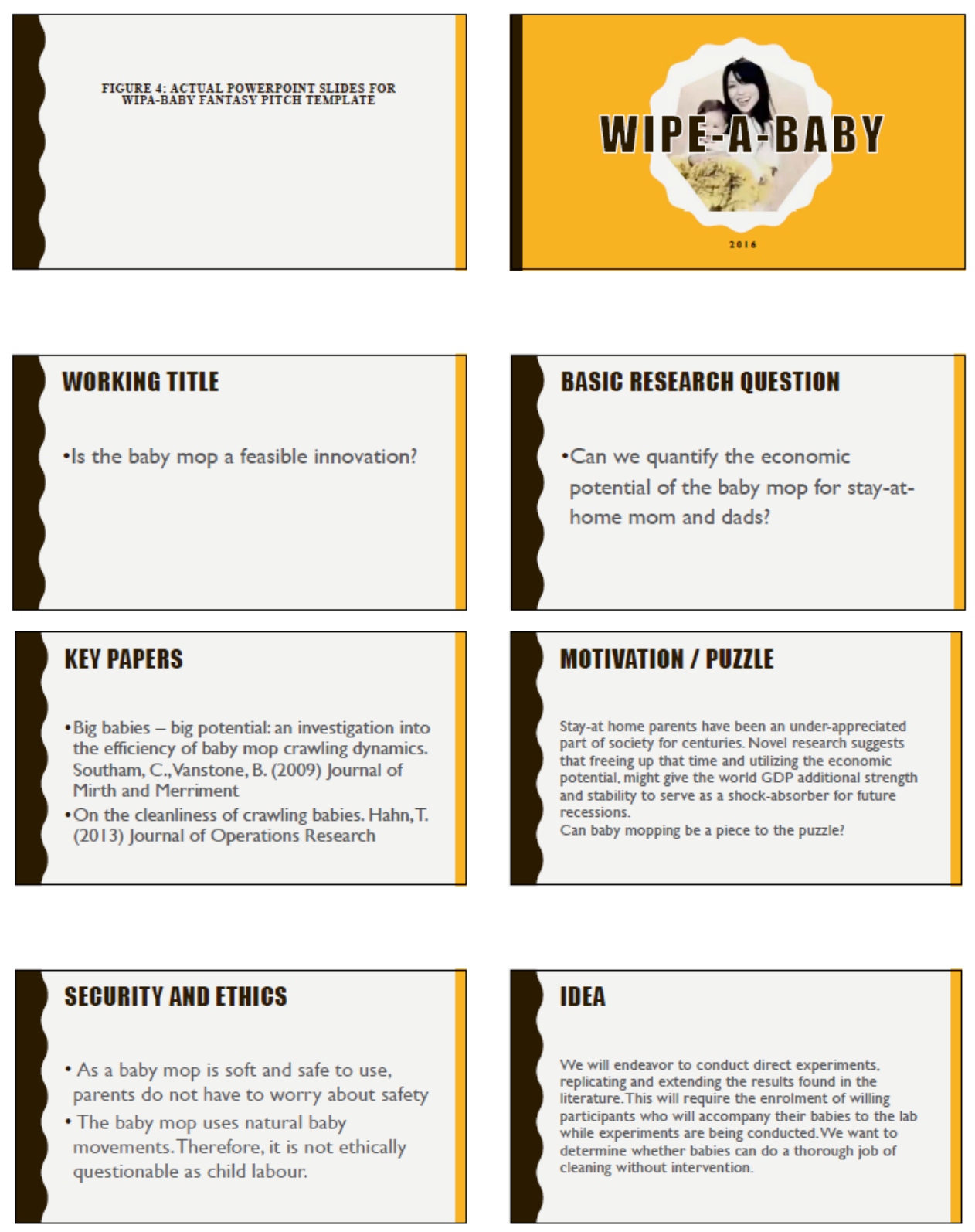

Figure 3: "Wipe-a-Baby" Pitch Slides 

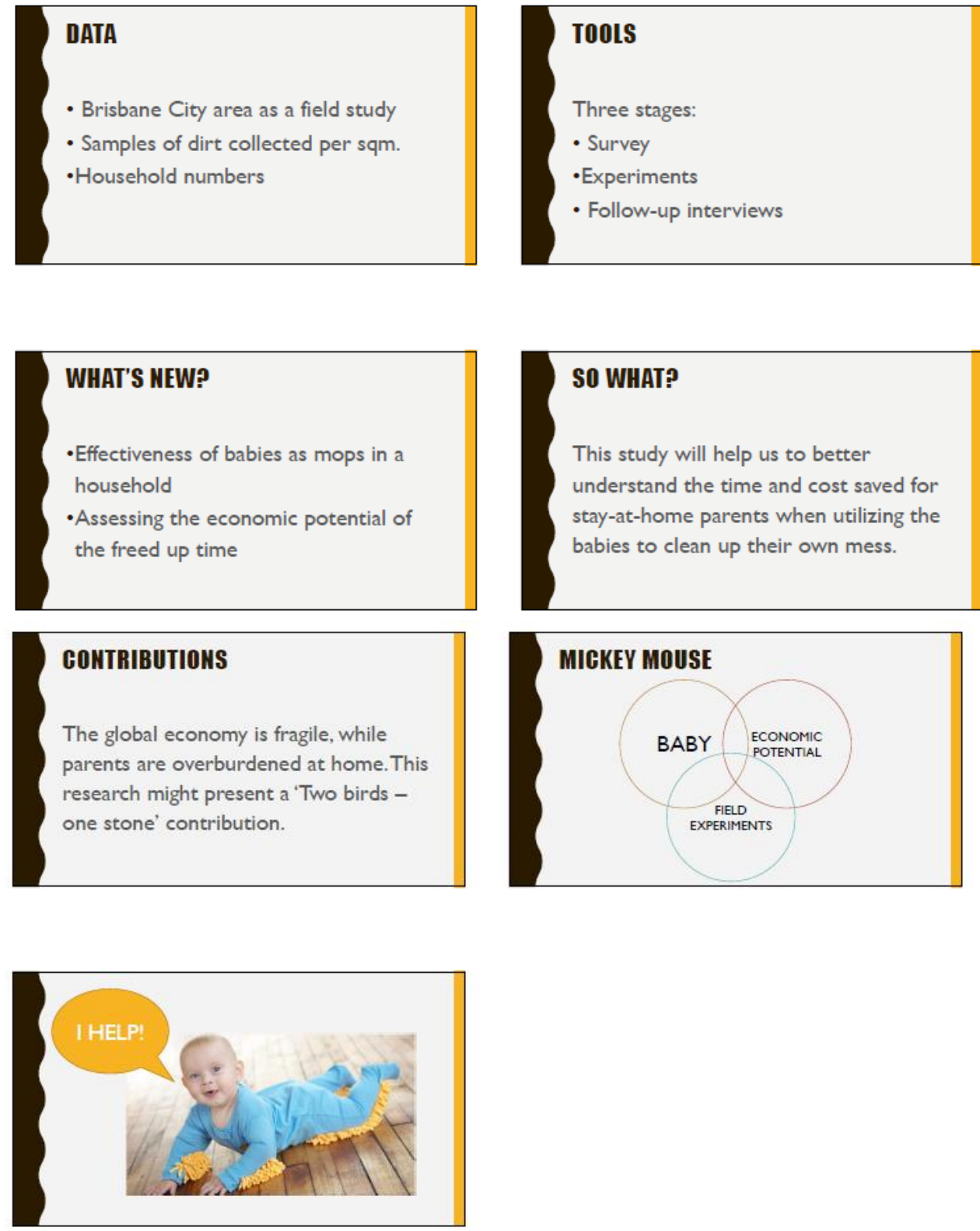

Figure 3: “Wipe-a-Baby" Pitch Slides (continued)

${ }^{\mathrm{i}}$ Recent examples of short papers that illustrate the application of the pitching template are: Ali (2016); Atif (2016); Beaumont (2015a, b); Brenner (2016); Ellis (2016); McKay and Haque (2016); Qureshi (2016); Rad (2016); Rahman (2016); Ratiu (2016); Ratiu (2015a, 
b); Rekker (2016); Shahzad (2016); Sivathaasan (2016); Unda (2015a, b); Wallan and Spry (2016) and Xue (2016).

ii Notably, various recent published articles acknowledge Faff's $(2015,2017)$ template as a critical research planning tool, e.g. Chang and Wee (2016); Menzies, Dixon and Rimmer (2016); Dang and Henry (2016); Mathuva (2016); and Sivathaasan, Ali, Liu and Haung (2017).

iii A free web portal provides a convenient means for pitch creation: PitchMyResearch.com

iv This complements the existing stable of PR papers in which Faff (2015) and Faff (2017) are at the core, with Faff (2017) representing the living "central clearinghouse" paper providing updated information/weblinks to the growing set of "pitching" resources and initiatives. The broader stable of "pitching research" papers comprise: Faff (2016a); Faff (2016b); Faff (2016c); Faff, Godfrey and Teng (2016); Faff, Ali, et al (2016); Faff, Carrick, Chen, Dallest, et al. (2017); Faff, Carrick, Chen, Escobar, Khong, Nguyen and Tunny (2017a and b); Faff and Kastelle (2016); Faff, Li, Nguyen and Ye (2016); Faff, Wallan, et al (2016); Faff, Lay and Smith (2016); Teng and Faff (2017); Nguyen, Faff and Haq (2017).

${ }^{\vee}$ The 2015 UQAPS pitching research competition final was video recorded and have been uploaded to YouTube. The addresses are as follows (the event introduction can be found are https://www.youtube.com/watch?v=CQ6I6ejgy4c):

1. Gill: https://www.youtube.com/watch?v=aaYchX039Fs

2. McCullough: https://www.youtube.com/watch?v=yvgbX9oClHo

3. Eats: https://www.youtube.com/watch?v=FlCRGpu2P9M\&feature=youtu.be

4. Mahmud: https://www.youtube.com/watch?v=czTkGJTwO2Y\&feature=youtu.be

5. Ndugwa: https://www.youtube.com/watch?v=RPNfHUolx5c\&feature=youtu.be

6. Gorji: https://www.youtube.com/watch?v=kBGEWPR1bUk\&feature=youtu.be

7. Noh: https://www.youtube.com/watch?v=KoUWH2LRmUE

vi AFDEN is the AFAANZ Doctoral Education Network. For more information, see the AFDEN web page: http://www.afaanz.org/doctoral-programs\#AFAANZDOCTOR ALEDUCATIONNETWORK

${ }^{\text {vii }}$ For example, see Faff (2016a). 